\title{
Cardiovascular Risk Factors and Visiting Nurse Intervention - Evaluation of a Croatian Survey and Intervention Model: the CroHort Study
}

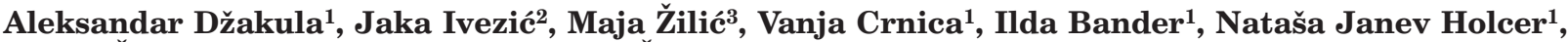 \\ Selma Šogorić ${ }^{1}$, Jadranka Pavić ${ }^{4}$, Mara Županić ${ }^{4}$ and Silvije Vuletićc \\ ${ }^{1}$ University of Zagreb, School of Medicine, "Andrija Štampar « School of Public Health, Zagreb, Croatia \\ ${ }^{2}$ Kutina Health Center, Visiting Nurse Service, Novska, Croatia \\ ${ }^{3}$ University of Zagreb, Zagreb University Hospital Centre, Zagreb, Croatia \\ ${ }^{4}$ University of Applied Health Studies, Zagreb, Croatia
}

\begin{abstract}
A B S T R A C T
The aim of this study is to identify factors that influence the success of the implementation of the primary and secondary prevention programs in Croatia by the visiting/community services. Two main sources of information were used: reports about regular visiting nurse services in Croatia and research about visiting nurse participation in the Croatian Adult Health Cohort Study (CroHort) 2008. Out of the total number 9,070 respondents who participated in CAHS 2003 survey, during CroHort 2008 program 3,229 (35.6\%) participants were re-interviewed. The qualitative analysis was done with a sample of 34 visiting nurses, which participated in the CroHort 2008. Results show that there are three key problems which limit preventive programs: inability of the health care system to recognize the importance of the primary prevention; visiting nurses' lack capacity to implement prevention and populations' lack of motivation and education.
\end{abstract}

Key words: cardiovascular diseases, risk factors, prevention, visiting nurse, CroHort study

\section{Introduction}

Primary prevention of cardiovascular diseases (CVD) implies the prevention of symptomatic diseases and the early recognition of the factors that influence it. It takes into account such factors as physical health, socioeconomic status, education, income, etc ${ }^{1-5}$. The main risk factors for developing CVD are obesity, hypertension, smoking, alcohol, high cholesterol, sedentary lifestyle, unhealthy diet, and diabetes mellitus ${ }^{6}$. Many of these factors are due to an unhealthy lifestyle ${ }^{4}$. The risk for development of CVD increases with the addition of each risk factor ${ }^{7}$. Morbidity and mortality due to CVD may be significantly decreased by changing one's lifestyle from unhealthy to healthy, which is the World Health Organization's main global strategy on the subject ${ }^{8}$.

There are many studies about effectiveness and efficiency of primary and secondary prevention of CVD. Some of these studies are conducted as randomized studies, some as evaluation of the existing programs.
For example, the Swedish randomized study of 151 men and women researched how intensive lifestyle modifications affect cardiovascular risk factors. The study showed that a program of intensive lifestyle modification for cardiovascular risk reduction can significantly help decrease development of CVD in a high risk group.

Randomized studies of 419 patients held in duration of 15 months (8-10 visits) in the USA researched the role of visiting nurses and dietitians with comparison to the usual health care personnel and sought to show a decrease of the main CVD risk factors. The intervention consisted of intensive individualized care, coordination with primary and specialty care, self-management support and behavioral counseling to improve physical activity, nutrition, weight management, stress reduction, and medication adherence. The study concluded that interventions done by visiting nurses and dietitians success- 
fully decreased multiple risk factors for development of CVD in a high-risk group ${ }^{10}$.

Systemic reviews done by authors from the University of Tennessee highlighted the importance of health promotion in areas such as: information, education, and encouragement of the population to adopt a healthy life style in order to improve and/or suppress habits which lead to development of heart and vessel diseases. Further, it stressed the importance of cooperation between the health system and the population ${ }^{11}$.

In a systemic review of seven randomized control trials that begun in 1985 until 2007, the Canadian authors studied if interventions on a lifestyle modification in primary health care could have an effect on risk factors associated with the development of the CVD in low-risk patients. They concluded that the intervention aimed at the low-risk population is of marginal importance; yet the aim should be on a high-risk population. Additionally, there was no difference if the intervention was conducted by a physician or a visiting nurse ${ }^{12}$.

In the Turkish follow up study of patients with arterial hypertension, the researchers examined the effectiveness of multiple interventions programs by nurses. The study concluded that there was a significant decrease in blood pressure, body mass index, and triglycerides in studied patients. The limit of this research was a small sample size and the lack of a control group ${ }^{13}$.

A study done in the Netherlands compared the efficiency of the primary prevention of CVD in a high-risk group of patients, implemented by either a family physician or a visiting nurse. After a one year period, there was a significant decrease of risk factors among the high-risk patients, with a bigger decrease in patients who were under a visiting nurse care. However, in many patients, the prevention was unsuccessful, which showed the need for improvement. It was concluded that visiting nurses, compared to family physicians, may achieve equal, or at time, better results in carrying out primary preventive actions aimed at reducing $\mathrm{CVD}^{14}$.

The role of visiting nurses in communities is to provide assistance and counseling to individuals, families and groups within the population, aiding them to achieve physical, social and mental potential ${ }^{15}$. Furthermore, the responsibilities of visiting nurses should be to promote and sustain health by suppressing the development of diseases. Additionally, one of their roles is to recognize and help prevent risky behaviors by increasing awareness and knowledge in health education. Visiting nurses have a chance to develop close relationships with health care users, so they can work on creating strategic interventions together ${ }^{16}$. Currently, the Croatian health care system employs 843 visiting nurses ${ }^{20}$. According to the Croatian Institute for Health Insurance, visiting nurses care for approximately 5,100 people. They provide care to all age groups in accordance to a specifically defined geographical area and community. Visiting nurses' tasks range from the following: to promote health care, to collaborate with other health care workers, to care for high-risk individuals, to work in prevention of chronic non-communicable diseases in order to increase life expectancy and the number of years without illness.

Results of the Croatian Adult Health Survey (CAHS) conducted in 2003 showed unsatisfactory behavioral risk factors for the development of CVD in a studied population, which resulted in the implementation of Croatian Adult Health Cohort Study (CroHort) 2008. In between the two surveys, there were no organized interventions on cardiovascular health. However, as a part of the Croatian Adult Health Cohort Study (CroHort) 2008, a pilot project was developed: »The Regionalism of Cardiovascular and Behavioral Risks - Intervention Model«. The project was carried out by visiting nurses with the primary goal to develop a system of primary and secondary CVD prevention. A special »health booklet « was designed to be used during the survey ${ }^{18}$.

Methodology and a content of the health booklet were designed in cooperation with the Croatian Nurses Association. It was designed for visiting nurses to follow as a document for assessing and modifying CVD risk factors in patients they followed up on during a one year period. Essentially, the health booklet would act as an independent visiting nurses' diagnostic guideline that would serve as an intervention model on CVD prevention. An intervention model is designed as a dynamic cooperation between a visiting nurse and a heath care user for detection of risk factors, negotiating and agreeing on common objectives and evaluations ${ }^{18}$.

The aim of this study was to identify factors that influence the success of the implementation of the primary and secondary prevention programs in Croatia by the visiting/community services, and to detect main opportunities and barriers for development of primary and secondary prevention through primary health care in Croatia.

\section{Methods}

Two main sources of information were used: reports about regular visiting nurse services in Croatia and reports and research about visiting nurse participation in the Croatian Adult Health Cohort Study (CroHort) 2008. Aim of CroHort was to contact and re-interview 9,070 respondents who participated in CAHS 2003, thus becoming the first follow-up study of CAHS 2003 cohort.

Legal position, duties, responsibilities and performance of the visiting nurse were analyzed out of official sources and documents which regulate their work in Croatia ${ }^{19}$. The analysis of the services provided by visiting nurses was based on official reports published in the Croatian Health Service Yearbook $2009^{20}$.

Reports on CroHort 2008 project activities were used to assess the validity of the survey and output of the interventions done in CroHort 2008 ${ }^{17}$. To assess the success of visiting nurses' performance of the primary prevention of CVD during CroHort 2008, the research was done using all 34 participants during the First Croatian Workshop on Cardiovascular Health 2007-2011. The research was done in Zadar on April 1 ${ }^{\text {st }}, 2009$. The method 
used was the interview method. All the workshop participants were interviewed, taking into the consideration the objectives of this study and the participant's knowledge about the study. Thirty-four participants were divided into 6 groups ( 2 groups with 5 participants and 4 groups with 6 participants) whose goal was to mutually analyze the importance and problems of the CroHort 2008 , as well as programs of the individualized intervention on cardiovascular health. The representative chosen from each group presented their group's conclusions about the CroHort 2008. In order to better interpret the participants' answers, all the conversations were noted and audio taped.

\section{Results}

\section{Curent situation and visiting nurse service performance}

According to the data on primary health care users, there is one visiting nurse per approximately 4,877 users. The Croatian Health Service Yearbook 2009 report indicates that there are 843 full-time visiting nurses and 141 part-time visiting nurses. In 2009, in this field of nursing, there were 781 nurses with a college education and 136 nurses with high school education. There were 24,132 visits made to pregnant women, 148,658 visits to puerperal women and 33,997 visits to other women registered. Furthermore, the results show 174,201 visits to newborns, 78,728 visits to infants, 25,775 visits to small children, 9,568 visits to other children and 1,210 visits to schools for the completion of the health education course. The most visits were made to chronically ill patients, which were listed at 759,279 . This was $3,4 \%$ more than in 2008 , with a more organized intent to instruct them about self-control and prevention of complications, and to administer treatment to the disabled and handicapped.

\section{Visiting nurse participation in the Croatian Adult Health Cohort Study 2008}

At the first Croatian Workshop on Cardiovascular Health 2007-2011, the results from the CroHort 2008 were presented. 3,229 (35.6\%) out of 9,070 respondents who participated in CAHS 2003 survey were re-interviewed, 5,841 (64.4\%) participants were recognized as non-respondents (Table 1 ).

To analyze the possible problems of the CroHort 2008 , a qualitative analysis was conducted with aim to collect the knowledge, experience, and opinions of professionals, with a goal to detect specific problems about the CroHort which can be used for improving the visiting nurses' work.

The qualitative analysis was done with a sample of 34 visiting nurses, who participated in the CroHort 2008 and were responsible for the coordination of the survey in their Health Care Center. The primary survey of the visiting nurses was conducted using an interview method, which was conducted during the workshops, in the
TABLE 1

STRUCTURE OF THE NON-RESPONDENTS IN CROATIAN ADULT HEALTH COHORT SURVEY 2008

\begin{tabular}{lcc}
\hline $\begin{array}{l}\text { Reasons for } \\
\text { non-response }\end{array}$ & $\begin{array}{c}\text { Number of } \\
\text { non-respondents }\end{array}$ & $\begin{array}{c}\text { \% of total } \\
\text { sample in 2003 }\end{array}$ \\
\hline Refused to participate & 3453 & 38.1 \\
Died & 808 & 8.9 \\
Unknown/contact not & 1580 & 17.4 \\
established & & \\
Total & 5841 & 64.4 \\
\hline
\end{tabular}

groups, individually, and using a sample. A total of 2448 words with 12022 signs were noted and analyzed.

Survey results were grouped into three levels:

1. General analysis of the interviews

2. Characteristics of the sentences

3. The main categories

General structure of the interview:

1. 6 focus groups

2. 52 characteristic sentences

3. 6 categories about the problems encountered during CroHort 2008

General analysis of the interviews

By the general analysis of conducted interviews, six categories were identified, which specify problems with the CroHort 2008, noticed by the visiting nurses: Territorial specificity, Position of the visiting nurse, Health care user's inability to recognize the importance of the primary health care, Need for specific education, Limits with the CroHort 2008 preparation, Unequal criteria during conduction of the CAHS 2003 and CroHort 2008 project (Table 2.).

\section{Discussion and Conclusion}

According to the law and to the visiting nurses' job description, the responsibilities of visiting nurses include health promotion and disease prevention, as well as a follow-up of a high-risk for disease development individuals. The Croatian Health Care plan is for visiting health services and its obligations are to increase life expectancy without chronic disease and/or disability.

The 2009 report by the Croatian Health Service Yearbook on visiting health services showed that the majority of visits were made to chronically ill patients. According to the report, visiting health services did not include visits to healthy individuals or individuals with one or more risk factors, to whom they should focus on because they are in need for primary and secondary prevention programs. In this case, there is an apparent discrepancy between the health care measurers set by the system and the measures used in the field.

These findings are confirmed by results of the CroHort 2008 , where $64.4 \%$ participants was recognized as non- 
TABLE 2

\section{PROBLEMS ADMINISTERING THE CROHORT 2008}

1. Territorial specificity - in one street located in an urban area an interviewer could reach five participants whereas another interviewer had to travel up to $120 \mathrm{~km}$ at times in order to reach the same number of participants - human migration

2. Position of the visiting nurse - visiting nurses' job is at times above their job description; they have to cover an area of more than 5100 inhabitants; work overload; unspecified description of services they need to provide

3. Health care user's inability to recognize the importance of the primary health care - indifference, lack of responsibility for their own health, to respondents are primarily important health services at secondary and tertiary level

4. Need for specific education - inadequate education of interviewers regarding individualized intervention planning; inadequate education of the visiting nurses

5. Limits with the CAHS 2008 preparation - unequal territory distribution; the success of the survey depended on visiting nurse's ability to communicate and organize; incorrect identification of subject's data; lack of basic resource for conducting a survey

6. Unequal criteria during conduction of the CAHS 2003 and CroHort 2008 project - inadequate motivation of the interviewers, no money reward; subjects stated that in 2003 they were appointed supervisors; surveys were done during the overtime and were paid; surveys were accompanied by official recommendation of the Minister but during conduction of CroHort 2008, that same was not the case.

-respondents, and among them $38.1 \%$ participants refused to cooperate with their visiting nurse. Moreover, for $17.4 \%$ of participants visiting nurses did not have any information even for the basis contact, although they are responsible for them.

The goal of the Visiting Nurses' Health Booklet was to help in applying the primary and secondary prevention of the CVD. Results show that there are three key problems which limit its adequate application. Those are: inability of the health care system to recognize the importance of the primary prevention and to focus visiting health services' attention to it; visiting nurses' lack of motivation, education, as well as resources to accurately implement the primary and secondary prevention; and populations' lack of motivation and education about the prevention programs.

Similar results are recognized through different models of CVD prevention in many countries ${ }^{9,10,12-14,21}$. Although similar problems with primary prevention exist in almost all health care systems there are many possibilities for improvement. Results of this study, and studies about public health care system ${ }^{22-24}$ carried out before show that there are few sources of problems and few

\section{R E F E R E N C E S}

1. MENSAH GA, MOKDAD AH, FORD ES, GREENLUND KJ, CROFT JB, Circulation 111 (2005) 1233. - 2. SUNDQUIST K, WINKLEBY M, AHLEN H, JOHANSSON SE, Am J Epidemiol 159 (7) (2004) 655. - 3. PICKETT KE, PEARL M, J Epidemiol Community Health, 55 (2001) 111. - 4. MACKAY J, MENSAH GA, MENDIS S, GREENLUND $\mathrm{K}$, The atlas of heart disease and stroke, WORLD HEALTH ORGANIZATION, 2004. - 5. WINKLEBY MA, JATULIS DE, FRANK E, FORTMANN SP, Am J Public Health, 82 (1992) 816. - 6 WORLD HEART FEDERATION, Cardiovascular health. Available from URL: http://www.world-heart-federation.org/cardiovascular-health/cardiovascular-disease-risk-factors/. - 7. SMITH SC, Am J Med, 120 (2007) S3. - 8. WORLD HEALTH ORGANIZATION, Global strategy on diet, physical activity and health. Available from: URL: http://www.who.int/ dietphysicalactivity/publications/ facts/cvd/en/. - 9. ERIKSSON MK FRANKS PW, ELIASSON M, PloS ONE 4 (2009) 1. - 10. MA J, BERRA $\mathrm{K}$, HASKELL WL, KLIEMAN L, HYDE S, SMITH MW, XIAO L, STAFFORD RS, Arch Intern Med, 169 (2009) 1988. - 11. DAGOGO-JACK S, EGBUONU N, EDEOGA C, Med Princ Pract, 19 (2010) 167. - stakeholder centers that maintain such situation and relations.

Given the foregoing, it is necessary for Croatia to define professional framework, strategy and operational programs of activities in the prevention of cardiovascular disease.

Professional framework must be based on the unity of primordial, primary and secondary prevention implemented through intersectoral networking. The strategy must define the action targeted to: individuals with increased risk; groups within which there is increased level of risk-taking behaviour; regions where the problems are more expressed; and hard to reach or deprived groups. Operational program must create a unique alliance for prevention of cardiovascular disease in primary care. This alliance has to operate through coordinated work of all health professionals and institutions in primary care.

\section{Acknowledgements}

This manuscript is prepared within the project of the Ministry of Science, Education and Sports, Grant No. 108-1080135-0264.

12. FLEMING P, GODWIN M, Can Fam Physician, 54 (2008) 1706. — 13. IRMAK Z, DUZOZ G, BOZYER I, Aust J Adv Nurs, 28 (2010) 60. - 14. VOOGDT-PRUIS HR, BEUSMANS GHMI, GORGELS APM, KESTER ADM, VAN REE JW, Br J Gen Pract, 60 (2010) 40. - 15. WORLD HEALTH ORGANIZATION, REGIONAL OFFICE FOR EUROPE, Highlights on Health in Croatia (WHO, Copenhagen, 2000). - 16. MOJSOVIĆ Z (ed), Sestrinstvo u zajednici (Visoka zdravstvena škola, Zagreb, 2004). - 17. VULETIĆ S, POLAŠEK O, KERN J, STRNAD M, BAKLAIĆ Ž, Coll Antropol, 33 Suppl 1 (2009) 3. - 18. PAVIĆ J, ŽUPANIĆ M, MUSIĆ MILANOVIĆ S, FIŠTER K, Coll Antropol, 33 Suppl 1 (2009) 81. — 19. Hrvatski zavod za zdravstveno osiguranje, Zakoni. Available from: URL: http://www.hzzo-net.hr/zakoni.htm. - 20. HZJZ, Croatian Health Service Yearbook 2009. Available from: URL: http://www.hzjz.hr/publikacije/ hzs ljetopis/. - 21. National Institute for Health and Clinical Excellence, Health systems and health-related behaviour change: a review of primary and secondary evidence. Available from: URL: http:// www.nice.org.uk/ media/0E6/62/SpecialReportHealthSystemsAndHealth RelatedBehaviour Change.pdf. - 22. DŽAKULA A, ŠOGORIĆ S, POLAŠEK O, JURIŠA A, 
ANDRIĆ A, RADAKOVIĆ N, TODOROVIĆ G, Coll Antropol, 33 Suppl 1 (2009) 87. - 23. ŠOGORIĆ S, DŽAKULA A, VUKUŠIĆ RUKAVINA T GROZIĆ ŽIVOLIĆ S, LAZARIĆ-ZEC D, DŽONO-BOBAN A, BRBOROVIĆ
O, LANG S, VULETIĆ S, Health Policy 89 (2009) 271. - 24. KOVAČEVIĆ J, ŠOGORIĆ S, DŽAKULA A, Acta Med Croatica, 64 (2010) 341.

\section{A. Džakula}

University of Zagreb, School of Medicine, „Andrija Štampar « School of Public Health, Rockefellerova 4, 10000 Zagreb, Croatia

e-mail:adzakula@snz.hr

\section{KARDIOVASKULARNI RIZIČNI ČIMBENICI I INTERVENCIJA PATRONAŽNIH SESTARA - EVALUACIJA ISTRAŽIVANJA U HRVATSKOJ I INTERVENCIJSKI MODEL: CROHORT STUDIJA}

\section{S A Ž E T A K}

Cilj istraživanja bio je prepoznavanje čimbenika koji utječu na uspješnost implementacije primarnih i sekundarnih preventivnih programa u Hrvatskoj, putem patronažnog sustava. Korištena su dva glavna izvora informacija: izvještaji o radu patronažnih sestara u Hrvatskoj i istraživanja o sudjelovanju patronažnih sestara u studiji CroHort 2008. Od 9,070 sudionika koji su sudjelovali u istraživanju CAHS 2003, tijekom CroHort 2008 programa je 3,229 (35,6\%) sudionika bilo ponovno intervjuirano. Napravljena je kvalitativna analiza na uzorku od 34 patronažnih sestara koje su sudjelovale $\mathrm{u}$ istraživanju CroHort 2008. Rezultati pokazuju tri ključna problema koja ograničavaju preventivne programe: nemogućnost zdravstvenog sustava da prepozna važnost primarne prevencije, nedovoljno mogućnosti patronažnih sestara za provođenje prevencije te nedostatak motivacije i edukacije u istraživanoj populaciji. 